\title{
Glucose-dehydrogenase-mediated Solute Transport and ATP Synthesis in Acinetobacter calcoaceticus
}

\author{
By B. J. VAN SCHIE, ${ }^{1} \dagger$ J. T. PRONK,${ }^{1}$ K. J. HELLINGWERF, ${ }^{2}$ \\ J. P. VAN DIJKEN ${ }^{1}$ AND J. G. KUENEN ${ }^{1 *}$ \\ ${ }^{1}$ Laboratory of Microbiology and Enzymology, Delft University of Technology, Julianalaan 67a, \\ 2628 BC Delft, The Netherlands \\ ${ }^{2}$ Department of Microbiology, University of Groningen, Kerklaan 30, 9751 NN Haren, \\ The Netherlands
}

(Received 25 February 1987; revised 6 July 1987)

\begin{abstract}
Evidence is presented that in Acinetobacter calcoaceticus oxidation of glucose to gluconate by the periplasmic quinoprotein glucose dehydrogenase (EC 1.1.99.17) leads to energy conservation. Membrane vesicles prepared from cells grown in carbon-limited chemostat culture exhibited (1) a high rate of glucose-dependent oxygen consumption and gluconate production, (2) glucosemediated cytochrome reduction, (3) uncoupler sensitive, glucose-dependent generation of a membrane potential and (4) glucose-driven accumulation of amino acids. Furthermore, oxidation of glucose to gluconate by whole cells was associated with ATP synthesis. These results confirm and extend previous observations that periplasmic glucose oxidation can act as a driving force for energy-requiring processes. It is therefore concluded that the incomplete oxidation of glucose by bacteria may serve as an auxiliary energy-generating system.
\end{abstract}

\section{INTRODUCTION}

Bacterial glucose metabolism can proceed via initial phosphorylation of the substrate or by direct oxidation to gluconate. This latter reaction is catalysed by a membrane-bound glucose dehydrogenase (GDH, EC 1 1 1.99.17). The enzyme is located on the periplasmic side of the cell membrane, which implies that the oxidation is an extracellular event (Dawes, 1981; Dokter et al., 1986). Frequently the turnover capacity of the glucose-oxidizing system exceeds that of gluconate uptake and metabolism. Thus, in the presence of excess glucose, gluconic acid is accumulated in the medium, a phenomenon already described by Boutroux (1880).

Dalby \& Blackwood (1955) first established the importance of GDH in the production of gluconate by bacteria with 'Aerobacter aerogenes' (Klebsiella pneumoniae). The characteristics of GDH from 'Bacterium anitratum' (Acinetobacter calcoaceticus) were extensively studied by Hauge (1960). The nature of the unusual cofactor of the enzyme was, however, established only recently: the enzyme belongs to the class of quinoproteins which have pyrrolo-quinoline quinone (PQQ) as the prosthetic group (Duine et al., 1986). GDH is coupled to the electron transport chain at the level of cytochrome $b$ (Hauge, 1960; Beardmore-Gray \& Anthony, 1986).

GDH has been detected in a wide range of Gram-negative bacteria of families such as Enterobacteriaceae, Pseudomonadaceae, Rhizobiaceae and Neisseriaceae (Ameyama et al., 1985; van Schie et al., 1985, 1987). The in vivo role of GDH has been the subject of many physiological

† Present address: Unilever Research Laboratory, Department of Bioprocessing, Olivier van Noortlaan 120, 3133 AT Vlaardingen, The Netherlands.

Abbreviations: DCCD, $N, N^{\prime}$-dicyclohexylcarbodiimide; GDH, glucose dehydrogenase; PMS, phenazine methosulphate; PQQ, pyrrolo-quinoline quinone; SF6847, 3,5-di-tert-butyl-4-hydroxybenzylidene-malonitrile; TPP, tetraphenylphosphonium. 
and genetic studies with a variety of organisms. Invariably, however, such studies have been carried out with bacteria which possess, in addition to GDH, alternative mechanisms of glucose metabolism. This seriously hinders the interpretation of results obtained with in vivo studies. In view of this complication we decided to study the energetics of glucose oxidation by GDH in $A$. calcoaceticus LMD 79.41. This organism constitutively synthesizes GDH (Visser et al., 1985) but is unable to grow on glucose or gluconate as the sole carbon source (Juni, 1978; van Schie, 1987). Preliminary results showed that in membrane vesicles of $\boldsymbol{A}$. calcoaceticus glucose oxidation leads to energy conservation (Pronk et al., 1985). This paper presents a more detailed study on the in vitro energetics of aldose oxidation in $A$. calcoaceticus LMD 79.41.

\section{METHODS}

Organism and growth. Acinetobacter calcoaceticus LMD 79.41 was obtained from the culture collection of the Laboratory of Microbiology and Enzymology, Delft. The organism was grown carbon-limited in an Applikon laboratory fermenter (working volume 1 litre) at a dilution rate of $0.15 \mathrm{~h}^{-1}$ and at $30^{\circ} \mathrm{C}$. In order to prevent foaming, aeration was accomplished by vortex mixing. The dissolved $\mathrm{O}_{2}$ tension was kept constant at $40 \%$ of air saturation by controlling the stirring rate. The $\mathrm{pH}$ was controlled at $7 \cdot 0$. The mineral medium was prepared according to van Schie et al. (1984). Sodium acetate ( $30 \mathrm{mM})$, alanine $(20 \mathrm{mM})$ or sodium $p$-hydroxybenzoate $(10 \mathrm{mM})$ were added as carbon sources.

Preparation of membrane vesicles. The procedure of Stinnett et al. (1973) was slightly modified. Cells from a carbon-limited continuous culture were harvested by centrifugation $(10000 \mathrm{~g}, 10 \mathrm{~min})$. The pellet was resuspended in an ice-cold solution containing $20 \%(\mathrm{w} / \mathrm{v})$ sucrose, $2.5 \%(\mathrm{w} / \mathrm{v}) \mathrm{LiCl}, 0.1 \%$ lysozyme, and $10 \mathrm{~mm}$-potassium phosphate, $\mathrm{pH} 7.0 / 10 \mathrm{mM}-\mathrm{MgSO}_{4}$, to a density of $2.5 \mathrm{~g}$ dry wt $\mathrm{l}^{-1}$. The suspension was heated to $30^{\circ} \mathrm{C}$ and then incubated for $90 \mathrm{~min}$ on a rotatory shaker at that temperature. The osmotically fragile spheroplasts were collected by centrifugation $(10000 \mathrm{~g}, 10 \mathrm{~min}$ ) and the pellet was resuspended by means of a hypodermic syringe (fitted with a needle of $1.5 \mathrm{~mm}$ diameter) in the smallest volume possible of the above buffer without lysozyme. This suspension was slowly added to 50 vols ice-cold lysis buffer $\left(10 \mathrm{~mm}\right.$-potassium phosphate, $\left.\mathrm{pH} 6 \cdot 6 / 1 \mathrm{~mm}-\mathrm{MgSO}_{4}\right)$ under vigorous stirring. DNAase and RNAase were added to a final concentration of $20 \mu \mathrm{g} \mathrm{ml}^{-1}$ each and the mixture was incubated at $30^{\circ} \mathrm{C}$ for $30 \mathrm{~min}$. During this incubation the light-scattering of the cell suspension decreased due to cell lysis. This suspension was then centrifuged at $40000 \mathrm{~g}$ for $10 \mathrm{~min}$ at $4{ }^{\circ} \mathrm{C}$ and the pellet was resuspended in 50 $\mathrm{ml}$ ice-cold buffer containing $100 \mathrm{~mm}$-potassium phosphate, $\mathrm{pH} 6.6 / 10 \mathrm{~mm}-\mathrm{MgSO}_{4}$. Whole cells and large fragments were removed by centrifugation at $3000 \mathrm{~g}$ for $10 \mathrm{~min}$. The supernatant was carefully decanted and the centrifugation step was repeated. The supernatant, which was devoid of whole cells as judged by phase contrast microscopy, was centrifuged $(40000 \mathrm{~g}, 10 \mathrm{~min})$ to collect membrane vesicles. The pellet was washed twice with the same buffer and the final pellet was resuspended to a final concentration of $1-5 \mathrm{mg}$ membrane protein $\mathrm{ml}^{-1}$. Vesicles were stored in liquid nitrogen.

Solute transport. With some batches of vesicles, anomalously low rates of alanine uptake were obtained, which could be enhanced by the addition of $N, N^{\prime}$-dicyclohexylcarbodiimide (DCCD) (see Results). Such preparations were discarded. Uptake assays were performed at $30^{\circ} \mathrm{C}$ in small test tubes (internal diameter $9 \mathrm{~mm}$, length 30 $\mathrm{mm}$ ). Membrane vesicle suspensions were rapidly thawed and diluted in a buffer containing $100 \mathrm{~mm}$-potassium phosphate, $\mathrm{pH} \mathrm{6.6/10} \mathrm{mM-MgSO}$ to give a final concentration of $0.2-0.5 \mathrm{mg}$ membrane protein $\mathrm{ml}^{-1}$. When intact cells were used the final concentration was $0.02-0.06 \mathrm{mg} \mathrm{dry} \mathrm{wt} \mathrm{ml}^{-1}$. The reaction mixture was aerated by rapid stirring with magnetic, Teflon coated, bars (length $7 \mathrm{~mm}$, diameter $2 \mathrm{~mm}$ ). The final volume of the reaction mixture after addition of electron donor and ${ }^{14} \mathrm{C}$-labelled solute was $100 \mu \mathrm{l}$. Membrane vesicles were preincubated with the appropriate electron donor for $1 \mathrm{~min}$ after which the uptake experiments were started by the addition.of the ${ }^{1+} \mathrm{C}$-labelled substrate (to a final concentration of $10 \mu \mathrm{M}$ ) with a Hamilton microsyringe. At the desired time the uptake reaction was terminated by dilution of the reaction mixture with $2 \mathrm{ml} 100 \mathrm{mM}-\mathrm{LiCl}$ and filtration through nitrocellulose filters $(20 \mathrm{~mm}$ diameter, $0.45 \mu \mathrm{m}$ pore size, Schleicher \& Schüll). After washing with $2 \mathrm{ml} 100 \mathrm{~mm}$ $\mathrm{LiCl}$ the radioactivity on the filters was counted in Scintillator 299 (Packard) using a Beckman 3801 scintillation counter (NEN).

Measurement of respiratory capacity. Respiration rates of whole cells and membrane vesicles were assayed polarographically with a Clark-type oxygen electrode (Yellow Springs Instruments). Vesicles were diluted in $100 \mathrm{~mm}$-potassium phosphate buffer $\left(\mathrm{pH} \mathrm{6.6)/10} \mathrm{mM-} \mathrm{MgSO}_{4}\right.$. Cells from carbon-limited chemostat cultures were assayed directly, without dilution, in the culture fluid. All determinations were carried out at $30^{\circ} \mathrm{C}$ and calculations were made on the basis of an oxygen concentration at that temperature of $225 \mathrm{nmol} \mathrm{O}_{2} \mathrm{ml}^{-1}$.

Measurement of membrane potential. The membrane potential was determined using a tetraphenyl phosphonium ${ }^{+}\left(\mathrm{TPP}^{+}\right)$-selective electrode as described previously (van Schie et al., 1985); correction for probebinding to the vesicle membranes was made according to Lolkema et al. (1982).

Electron microscopy. Vesicles were prefixed with $3 \%(\mathrm{v} / \mathrm{v})$ glutaraldehyde and $1 \%(\mathrm{w} / \mathrm{v})$ tannic acid in $0.1 \mathrm{M}$ - 
cacodylate buffer $\mathrm{pH} 7 \cdot 2$ for $1 \mathrm{~h}$, washed five times with the same buffer and fixed with $1 \%(\mathrm{w} / \mathrm{v})$ osmium tetroxide in $0.1 \mathrm{M}$-cacodylate buffer $\mathrm{pH} 7 \cdot 2$, containing $10 \mathrm{mM}-\mathrm{CaCl}_{2}$ for $17 \mathrm{~h}$ at room temperature. After fixation the vesicles were stained with $1 \cdot 5 \%(\mathrm{w} / \mathrm{v})$ aqueous uranyl acetate during dehydration at the $50 \%(\mathrm{v} / \mathrm{v})$ ethanol step and finally embedded in Spurr resin. Ultra-thin sections, post-stained with uranylacetate and Reynolds lead citrate, were examined in a Philips EM 201 electron microscope.

Cytochrome analysis. Absorption difference spectra of membrane vesicles were recorded with a Beckman UV 5260 spectrophotometer at room temperature. The protein concentration was $1.7 \mathrm{mg} \mathrm{ml}^{-1}$ and glucose (40 mM) was added as electron donor; for complete reduction a few grains of dithionite were added. The cytochrome $b$ content was estimated from the difference in absorption between 560 and $575 \mathrm{~nm}$, assuming an absorption coefficient of $22 \mathrm{mM}^{-1} \mathrm{~cm}^{-1}$ (Jones \& Poole, 1985).

Measurement of ATP synthesis. Intracellular ATP levels were measured in chemostat cultured cells. Samples were starved for 2-3 h to deplete the ATP pool and diluted 100 -fold in $0.9 \% \mathrm{NaCl}$. ATP was measured using a commercially available luciferin-luciferase bioluminescence assay system (M 2010 A Biocounter, LUMAC/3M).

Analytical assays. A Beckman model 915B Tocamaster total organic carbon analyser was used to determine the cellular carbon content. Bacterial dry weight was calculated assuming a carbon content of $50 \%$. Protein was measured by the Lowry method with bovine serum albumin as standard.

Chemicals. Lysozyme, DNAase and RNAase were obtained from Sigma. $\left[{ }^{14} \mathrm{C}\right] A$ lanine $\left(170 \mathrm{mCi} \mathrm{mmol}^{-1}, 6 \cdot 29\right.$ $\left.\mathrm{GBq} \mathrm{mmol}{ }^{-1}\right) ;\left[{ }^{14} \mathrm{C}\right.$ glutamic acid $\left(125 \mathrm{mCi} \mathrm{mmol}^{-1}, 4.63 \mathrm{GBq} \mathrm{mmol}^{-1}\right) ;\left[{ }^{14} \mathrm{C}\right]$ glycine $\left(117 \mathrm{mCi} \mathrm{mmol}^{-1}, 4.33\right.$ GBq mmol-1); $\left[{ }^{14} \mathrm{C}\right]$ leucine $\left(125 \mathrm{mCi} \mathrm{mmol}^{-1}, 4.63 \mathrm{GBq} \mathrm{mmol}^{-1}\right)$ and $\left[{ }^{14} \mathrm{C}\right]$ acetic acid $\left(60 \mathrm{mCi} \mathrm{mmol}^{-1}, 2 \cdot 22 \mathrm{GBq}^{-1}\right.$ $\left.\mathrm{mmol}^{-1}\right)$ were obtained from NEN. $\left[{ }^{14} \mathrm{C}\right] \mathrm{Gluconic}$ acid $\left(240 \mathrm{mCi} \mathrm{mmol}^{-1}, 8.89 \mathrm{GBq} \mathrm{mmol}^{-1}\right)$ was obtained from CEA, Service des molécules marquées. The uncoupler 3,5-di-tert-butyl-4-hydroxybenzylidene-malonitrile (SF6847) was a gift of Dr Y. Nishizawa (Sumitonmo Chemical Industry, Osaka, Japan).

\section{RESULTS}

\section{Preparation and respiratory characterization of membrane vesicles}

The technique of Stinnett et al. (1973) for the preparation of membrane vesicles of Pseudomonas aeruginosa proved to be applicable to A. calcoaceticus. Routinely $40-60 \mathrm{mg}$ membrane protein was obtained from $1 \mathrm{~g}$ cells $(\mathrm{dry} \mathrm{wt})$. Membrane vesicles were free of whole

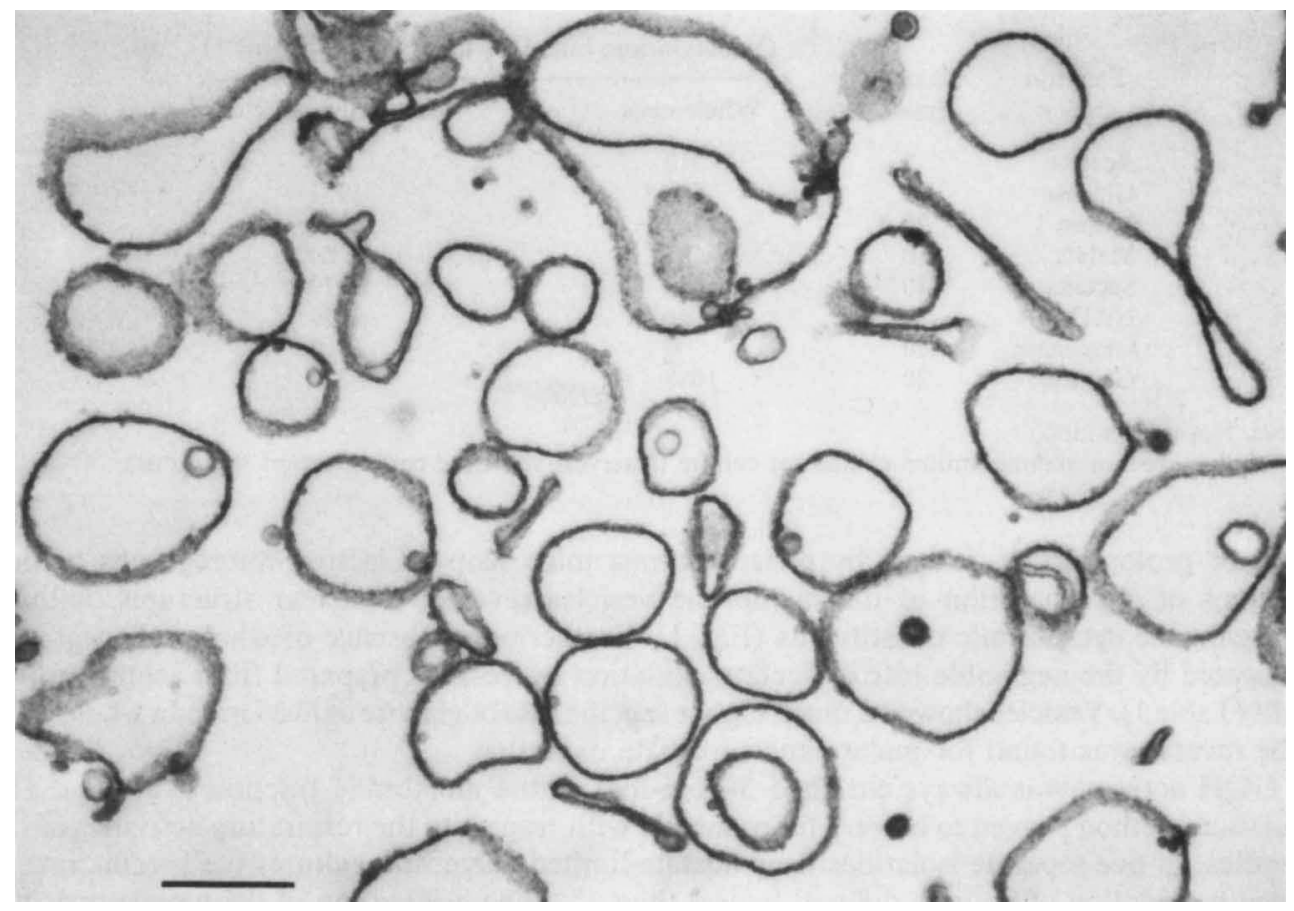

Fig. 1. Electron micrograph of a thin section of membrane vesicles of $A$. calcoaceticus, prepared from an acetate-limited chemostat culture. Bar, $0.50 \mu \mathrm{m}$. 


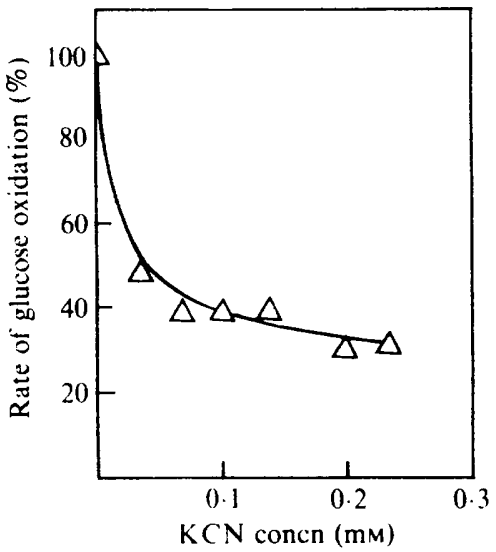

Fig. 2

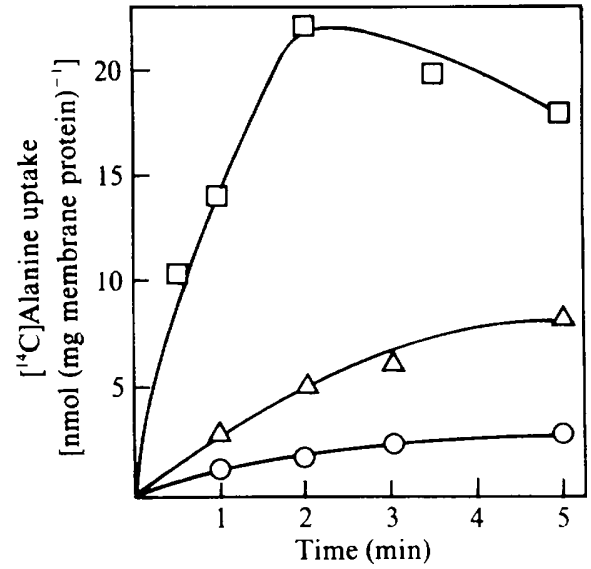

Fig. 3

Fig. 2. Inhibition of glucose oxidation in membrane vesicles prepared from acetate-limited chemostat cultures of $\boldsymbol{A}$. calcoaceticus by cyanide. The rate of glucose oxidation is expressed as a percentage of the value without inhibitor $\left[1900 \mathrm{nmol} \mathrm{O}_{2} \min ^{-1}(\mathrm{mg} \text { protein })^{-1}\right]$.

Fig. 3. Uptake of $\left[{ }^{1+} \mathrm{C}\right]$ alanine by membrane vesicles from $A$. calcoaceticus. The organism was grown in the chemostat under limitation of different carbon and energy sources. Solute transport was energized by electron transfer via PQQ-dependent glucose dehydrogenase. Alanine uptake in the absence of an electron donor was negligible. Vesicles were isolated from cells grown on acetate $(O), p$ hydroxybenzoate $(\triangle)$, and alanine $(\square)$.

\section{Table 1. Respiration rates of whole cells and membrane vesicles of A. calcoaceticus}

A. calcoaceticus preparations were obtained from continuous cultures grown at a dilution rate of $0 \cdot 15 \mathrm{~h}^{-1}$ and at $30^{\circ} \mathrm{C}$. Unless indicated otherwise, cells were cultured under acetate limitation (reservoir substrate concentration $30 \mathrm{~mm}$ ).

$\begin{array}{lccc}\begin{array}{l}\text { Electron } \\ \text { donor }\end{array} & \begin{array}{c}\text { Concn } \\ (\mathrm{mM})\end{array} & \overbrace{\text { Whole cells }}^{\text {Oxidation rate }\left[\mathrm{nmol} \mathrm{O}_{2} \mathrm{~min}^{-1}(\mathrm{mg} \text { protein })^{-1}\right]} \\ \text { Acetate } & 5 & 510 & \text { Membrane vesicles } \\ \text { Glucose } & 20 & 540 & 0 \\ \text { Xylose } & 20 & 530 & 1957 \\ \text { Malate } & 10 & 185 & 1941 \\ \text { Succinate } & 10 & 210 & 84 \\ \text { NADH } & 10 & \mathrm{ND} & 79 \\ \text { Gluconate } & 20 & 0 & 1220 \\ \text { Glucose* } & 20 & 1088 & 3300\end{array}$

ND, Not determined.

* Cells grown in alanine-limited chemostat culture (reservoir substrate concentration $=20 \mathrm{~mm}$ ).

cells or protoplasts, as judged by phase contrast microscopy. Electron micrographs of thin sections of a preparation of the membrane vesicles revealed vesicular structures, without recognizable cytoplasmic constituents (Fig. 1). Furthermore, absence of whole cells was also indicated by the negligible rate of acetate oxidation by vesicles prepared from acetate-grown cells (Table 1). Vesicles showed a much higher specific rate of glucose oxidation than whole cells. The reverse was found for malate and succinate oxidation.

GDH activity was always enriched 3- to 6-fold in the membrane fraction (Table 1). The isolation method proved to be very reproducible with respect to the respiratory activities of the vesicles. In five separate isolations from acetate-limited chemostat cultures the specific rate of glucose oxidation of vesicles differed by less than $3 \%$. The orientation of the vesicles was not investigated in detail, but it seems likely that their orientation was right side out. This can be concluded from their bioenergetic parameters (see below) and from the fact that glucose, which 
Table 2. Initial rate of solute uptake by membrane vesicles and whole cells from acetate-limited chemostat cultures of $A$. calcoaceticus, energized by electron transfer via the $P Q Q$-dependent $G D H$

\begin{tabular}{lcc} 
& \multicolumn{2}{c}{ Initial uptake rate [nmol $\min ^{-1}\left(\mathrm{mg} \mathrm{protein}^{-1}\right.$ ] } \\
\cline { 2 - 3 } Amino acid & Cells & Membrane vesicles \\
Alanine & 12 & 2.5 \\
Glycine & ND & 1.0 \\
Leucine & ND & $0 \cdot 6$ \\
Glutamate & ND & 0.8 \\
Acetate & 40 & 0.05 \\
Gluconate & 0.8 & 0.25 \\
& ND, Not determined
\end{tabular}

Table 3. Effect of various electron donors on alanine transport in vesicles obtained from acetate-limited cells of $A$. calcoaceticus

$\begin{array}{lcc}\text { Electron donor } & \begin{array}{c}\text { Concn } \\ (\mathrm{mM})\end{array} & \left.\begin{array}{c}\text { Initial uptake rate } \\ \text { [nmol min }\end{array} \mathrm{mg}^{-1} \text { membrane protein }\right)^{-1} \text { ] } \\ \text { Glucose } & 20 & 1 \cdot 3 \\ \text { Xylose } & 20 & 1 \cdot 2 \\ \text { PMS-ascorbate } & 0 \cdot 2 / 20 & 1 \cdot 35 \\ \text { NADH } & 10 & 0 \\ \text { Gluconate } & 20 & 0 \\ \delta \text {-Gluconolactone } & 20 & 0 \\ \text { Malate } & 10 & 0 \cdot 4\end{array}$

was not taken up by whole cells and vesicles (data not shown), was oxidized by cells and vesicles with nearly the same affinity constant $(1.1$ and $0.8 \mathrm{mM}$ respectively).

Various respiratory chain inhibitors were tested for their effect on the glucose-dependent $\mathrm{O}_{2}$ consumption of vesicles. Glucose oxidation was partly sensitive to $\mathrm{KCN}$. Low concentrations (less than $0.1 \mathrm{~mm}$ ) caused $60 \%$ inhibition (Fig. 2), a value which hardly increased with increasing $\mathrm{KCN}$ up to $1 \mathrm{mM}$. Glucose oxidation was insensitive to antimycin $\mathrm{A}(8 \mu \mathrm{M})$. Addition of rotenone $(30 \mu \mathrm{M})$ or myxothiazole $(4 \mu \mathrm{M})$ resulted in a partial reduction of glucose-dependent $\mathrm{O}_{2}$ uptake (27 and $50 \%$ inhibition, respectively). Glucose oxidation was very sensitive to DCCD. Addition of $22 \mu \mathrm{M}$ DCCD inhibited glucose oxidation by $50 \%$.

Active uptake of solutes by membrane vesicles

Electron transfer from glucose to $\mathrm{O}_{2}$ via GDH energized the transport of several amino acids. In vesicles from acetate-grown cells alanine was accumulated with the highest initial rate (Table 2) and therefore this amino acid was used in further experiments. Unlike whole cells, membrane vesicles did not accumulate acetate.

Membrane vesicles, prepared from chemostat cells grown on different carbon sources, were all transport-active, albeit that initial uptake rates and plateau levels of accumulated alanine differed. Initial uptake rates were highest for vesicles prepared from alanine-limited cells [20 nmol alanine $\min ^{-1}(\mathrm{mg} \text { membrane protein })^{-1}$, Fig. 3]. The same was found for whole cells: alanine-grown cells transported alanine more rapidly than acetate-grown cells [80 and $12 \mathrm{nmol}$ alanine $\mathrm{min}^{-1}$ (mg dry wt) $)^{-1}$, respectively].

The effect of various electron donors on alanine transport was studied in membrane vesicles prepared from acetate-grown cells (Table 3). Xylose and the artificial electron donor system phenazine methosulphate (PMS) plus ascorbate were as effective as glucose in energizing transport. Malate-driven alanine uptake was lower than with aldoses as electron donor. Gluconate and gluconolactone were not able to energize transport (Table 3). NADH, which in contrast to gluconate was rapidly oxidized by vesicles (Table 1), was also ineffective. Although, 


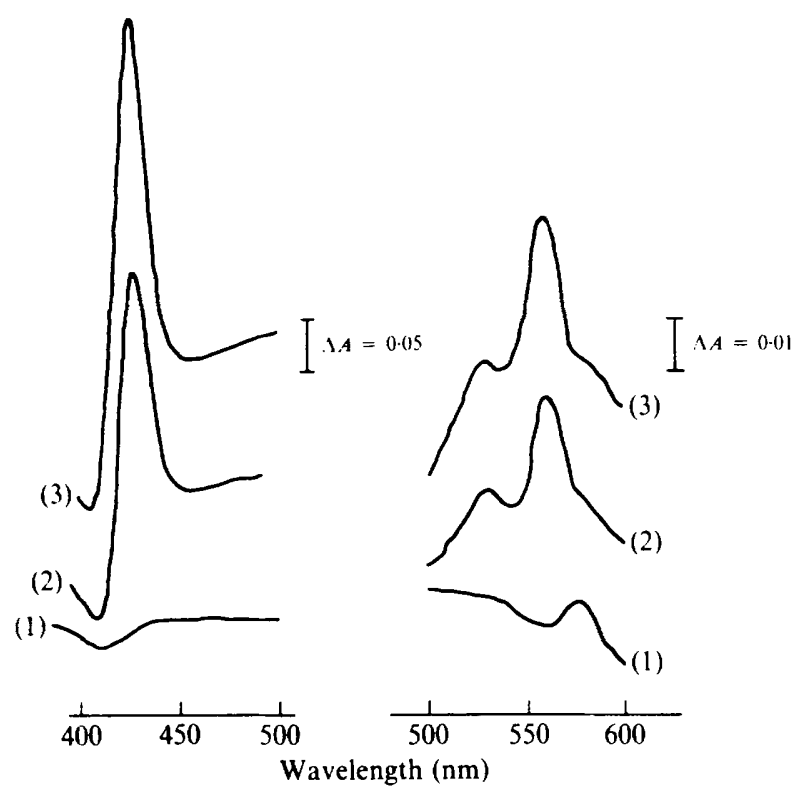

Fig. 4. Analysis of respiratory components present in membrane vesicles isolated from acetate grown A. calcoaceticus. The base-line (1) was obtained by scanning aerated membranes $\left(1.7 \mathrm{mg}\right.$ protein $\left.\mathrm{ml}^{-1}\right)$ present in sample and reference cuvettes. Glucose $(40 \mathrm{~mm})$ was added to the sample cuvette and the difference spectrum was recorded (2). Complete reduction of the membranes in the sample cuvette was obtained by adding dithionite (3).

as mentioned above, the glucose-oxidizing capacity of vesicles from acetate-grown cells was the same in different batches, this did not hold for the rate of alanine transport. Occasionally preparations were obtained which exhibited uptake rates 2 - to 5-fold lower than usual. Addition of low concentrations of DCCD $(50 \mu \mathrm{M})$ restored uptake to normal rates. The cause of the deviating behaviour of such preparations is unknown. In most preparations ( 7 out of 10 ) the high rate of alanine transport was not stimulated by addition of DCCD. In such vesicles alanine was accumulated 500 - to 1000 -fold assuming a specific volume of $2 \mu$ (mg membrane protein $)^{-1}$ (Kaback \& Barnes 1971), which implies an alanine gradient of $150-180 \mathrm{mV}$.

\section{Coupling of glucose dehydrogenase to the electron transport chain}

Membrane vesicles prepared from acetate-grown cells were examined for the presence of cytochromes by oxidized minus reduced difference spectra. Reduction with glucose revealed the presence of a $b$-type cytochrome with peaks at 565 and $529 \mathrm{~nm}$, and a broad Soret peak with a maximum at $428 \mathrm{~nm}$ (Fig. 4). As compared to dithionite about $70 \%$ of the cytochromes were reduced with glucose as electron donor. From the dithionite reduced minus oxidized difference spectrum a cytochrome $b$ concentration of $0 \cdot 3 \mathrm{nmol}(\mathrm{mg} \text { membrane protein })^{-1}$ was calculated.

\section{Generation of a membrane potential}

Since active transport can be energized by the oxidation of glucose, electron transfer from glucose to $\mathrm{O}_{2}$ via the respiratory chain should generate a transmembrane electrochemical potential $(\Delta \psi$, interior negative and/or $\Delta \mathrm{pH}$, interior alkaline). Measurements with a TPP+. selective electrode showed a glucose- and xylose-driven $\Delta \psi$ formation of about $110 \mathrm{mV}$. Addition of the uncoupler SF6847 at a concentration of $500 \mu \mathrm{M}$ completely abolished glucosedriven $\Delta \psi$ generation. The concentration of SF6847 required to reduce $\Delta \psi$ by $50 \%$ was approximately $30 \mu \mathrm{M}$. 


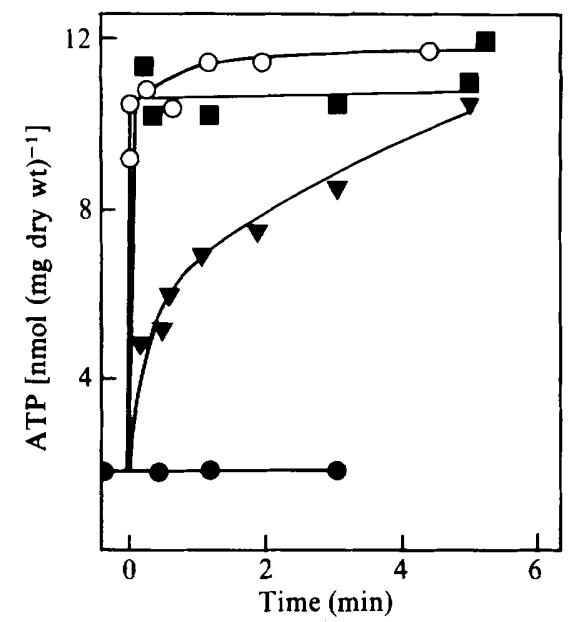

Fig. 5. ATP synthesis in whole cells of $A$. calcoaceticus. Cells grown in acetate-limited continuous culture were starved to deplete the intracellular ATP pool. When endogenous respiration was zero and the cytoplasmic ATP concentration was low, the formation of ATP was measured as a function of time after addition of $20 \mathrm{~mm}$-glucose $(O), 20 \mathrm{~mm}$-xylose $(\boldsymbol{D}), 5 \mathrm{~mm}$-acetate $(\boldsymbol{A})$ or $20 \mathrm{~mm}$-gluconate $(\boldsymbol{O})$.

\section{ATP synthesis by whole cells}

From the in vitro experiments described above it is clear that in A. calcoaceticus the oxidation of glucose to gluconate is associated with the formation of a proton motive force that can energize active solute transport. Additional evidence for GDH-mediated energy conservation was sought in the measurement of ATP synthesis by whole cells. $A$. calcoaceticus is well suited for this type of experiment since addition of glucose to whole cells results in a stoichiometric oxidation of the sugar according to the equation 1 glucose $+\frac{1}{2} \mathrm{O}_{2} \rightarrow 1$ gluconate (van Schie $e t$ al., 1984).

Cells of an acetate-limited continuous culture were starved for $2-5 \mathrm{~h}$ to lower the steady state concentration of intracellular ATP from 16 to $2 \mathrm{nmol}$ ATP (mg dry wt) ${ }^{-1}$. Addition of nonoxidizable substrates such as gluconate, lactose or alanine did not affect the ATP level in these cells. Addition of glucose, xylose or 2-deoxyglucose (all substrates of GDH), however, resulted in a rapid increase of the intracellular ATP concentration (Fig. 5). Addition of acetate also resulted in ATP synthesis, although at a lower rate than with glucose.

\section{DISCUSSION}

The present investigation clearly demonstrates that the oxidation of glucose to gluconate by the quinoprotein GDH can energize the transport of a number of amino acids in $A$. calcoaceticus LMD 79.41. These results confirm and extend earlier observations of GDH-mediated transport of solutes in membrane vesicles from P. aeruginosa (Stinnett et al., 1973) and Escherichia coli (van Schie et al., 1985).

Vesicles were prepared from cells grown under well-defined environmental conditions. Chemostat cultivation in general is well-suited for the study of the relationship between the physiological status of a cell and solute transport, but is seldom used as such. The method described here is also applicable to chemostat-grown E. coli B (B. J. van Schie, unpublished data). In addition, energization of active solute transport via periplasmic glucose oxidation with GDH is an ideal physiological system, since the dehydrogenase is directly accessible from the external medium. The activity of glucose dehydrogenase in the membrane vesicles was very high, the oxidation rate of glucose being 10-20 times faster than that of malate or succinate. Rates of $\mathrm{O}_{2}$ consumption with the latter two substrates were in the same order of magnitude as those reported for membrane vesicles of other organisms (Konings, 1977). Membrane vesicles 
isolated from alanine-grown cells transported alanine with an initial uptake rate that was five times higher than that of acetate-grown cells, probably as a result of the presence of a higher concentration of transport carriers for alanine in the membrane.

Although vesicles usually exhibited high rates of glucose oxidation and alanine transport, occasionally the transport activity was low. In such preparations the ATPase complex had probably been damaged during isolation : addition of the ATPase inhibitor DCCD restored $\Delta \psi$ generation and transport activity to the usual value, probably by preventing ATPase-associated proton leakage. A similar phenomenon (stimulation of active transport by DCCD) has also been observed with ATPase mutants of $E$. coli (van Thienen \& Postma, 1973). It is noteworthy that the stimulation of active transport by DCCD in certain vesicle preparations occurred despite the fact that DCCD inhibited glucose oxidation. This finding is consistent with the observation of van Schie et al. (1985) that $\Delta \psi$ generation and energization of active transport can function optimally even at submaximal respiration rates.

Electron transport from GDH proceeds via cytochrome $b$ (Hauge, 1960; Beardmore-Gray \& Anthony, 1986). In $A$. calcoaceticus terminal oxidation may proceed via cytochrome $o$ or cytochrome $d$. The level of these cytochromes in the membrane is dependent upon the $\mathrm{O}_{2}$ concentration in the growth medium (Ensley \& Finnerty, 1980). Cytochrome $d$ levels are known to increase with decreasing dissolved $\mathrm{O}_{2}$ concentration and cytochrome $d$ is less sensitive to cyanide than cytochrome $o$ (Jones \& Poole, 1985). Since in acetate-grown cells addition of $0.1 \mathrm{mM}-\mathrm{KCN}$ resulted in only partial inhibition of glucose oxidation (Fig. 2), it can be concluded that electrons from GDH can be transferred not only to cytochrome $o$, but also to a relatively cyanide insensitive terminal cytochrome oxidase, probably cytochrome $d$.

Analysis of intracellular ATP levels in starved cells of $\boldsymbol{A}$. calcoaceticus revealed an efficient coupling between glucose oxidation and ATP synthesis. Oxidative phosphorylation energized by glucose oxidation via a membrane-bound GDH has been demonstrated previously in Gluconobacter liquefaciens (Stouthamer, 1962). The rate of build-up of the ATP pool with glucose as a substrate was much faster than with acetate, although the rate of $\mathrm{O}_{2}$ consumption with both substrates was comparable. The difference is most likely due to the fact that glucose is oxidized in the periplasm, whereas acetate must be taken up and transformed to acetyl-CoA at the expense of ATP before energy can be produced. In addition acetate, in contrast to glucose, allows biosynthesis, which will drain the ATP pool.

The results demonstrate that the oxidation of glucose via GDH can be effectively used for the energization of cellular energy-consuming processes. It is therefore not surprising that during growth of $A$. calcoaceticus in chemostat cultures on mixtures of acetate and glucose the cell yield is much higher than during growth on acetate alone (van Schie et al., 1987). Taken together these results provide strong evidence for the physiological importance of GDH in the energy budget of A. calcoaceticus. In view of previous results (van Schie et al., 1985) it seems highly probable that the same applies to the physiological role of GDH in a large variety of other bacteria.

We are indebted to Mrs W. H. Batenburg-van der Vegte for performing the electron microscopy of membrane vesicles and to $P$. Dokter who recorded the cytochrome spectra. This study was supported by a grant of the Dutch Organization for the Advancement of Scientific Research (ZWO).

\section{REFERENCES}

Ameyama, M., Nonobe, M., Hayashi, M., Shinagawa, E., Matsushita, K. \& Adachi, O. (1985). Mode of binding of pyrroloquinoline quinone to apoglucose dehydrogenase. Agricultural and Biological Chemistry 49, 1227-1231.

BeARdmore-Gray, M. \& ANTHONY, C. (1986). The oxidation of glucose by Acinetobacter calcoaceticus: interaction of the quinoprotein glucose dehydrogenase with the electron transport chain. Journal of General Microbiology 132, 1257-1268.
Boutroux, L. (1880). Sur une fermentation nouvelle du glucose. Comptes rendus hebdomadaires des séances de l'Academie des sciences 91, 236-238.

Dalby, A. \& BlackwOOD, A. C. (1955). Oxidation of sugars by an enzyme preparation from Aerobacter aerogenes. Canadian Journal of Microbiology 1, 733742.

DAwes, E. A. (1981). Carbon metabolism. In Continuous Culture of Cells, vol. 2, pp. 1-38. Edited by P. H. Calcott. Boca Raton, Florida: CRC Press. 
Dokter, P., Frank, JzN, J. \& Duine, J. A. (1986) Purification and characterization of quinoprotein glucose dehydrogenase from Acinetobacter calcoaceticus LMD 79.41. Biochemical Journal 239, 163-167.

Duine, J. A., Frank, JzN, J. \& Jongejan, J. A. (1986). PQQ and quinoprotein enzymes in microbial oxidations. FEMS Microbiology Reviews 32, 165-178.

ENSLEY, B. D. \& FINNERTY, W. R. (1980). Influences of growth substrates and oxygen on the electron transport system in Acinetobacter sp. H01-N. Journal of Bacteriology 142, 859-868.

Hauge, J. G. (1960). Purification and properties of glucose dehydrogenase and cytochrome $b$ from Bacterium anitratum. Biochimica et biophysica acta 45 , 250-262.

JoNes, C. W. \& Poole, R. K. (1985). The analysis of cytochromes. Methods in Microbiology 18, 285-328.

JUNI, E. (1978). Genetics and physiology of Acinetobacter. Annual Review of Microbiology 32, 349-371.

KABACK, H. R. \& BARNES, E. M. (1971). Mechanism of active transport in isolated membrane vesicles. II. The mechanism of energy coupling between D-lactic dehydrogenase and $\beta$-galactoside transport in membrane preparations from Escherichia coli. Journal of Biological Chemistry 246, 5523-5531.

KoNINGS, W. N. (1977). Active transport of solutes in bacterial membrane vesicles. Advances in Microbial Physiology 15, 175-251.

Lolkema, J. S., Hellingwerf, K. J. \& Konings, W. N. (1982). The effect of 'probe binding' on the quantitative determination of the proton motive force in bacteria. Biochimica et biophysica acta $\mathbf{6 8 1}$, 85-94.

Pronk, J. T., van Schie, B. J., van Dijken, J. P. \& KUENEN, J. G. (1985). Energization of solute transport by $\mathrm{PQQ}$-dependent glucose dehydrogenase in membrane vesicles of Acinetobacter species. Antonie van Leeuwenhoek 51, 560.
VAN SCHIE, B. J. (1987). The physiological function of gluconic acid production in Acinetobacter species and other Gram-negative bacteria. PhD thesis, Delft University of Technology, The Netherlands.

van Schie, B. J., van DiJken, J. P. \& Kuenen, J. G. (1984). Non-coordinated synthesis of glucose dehydrogenase and its prosthetic group PQQ in Acinetobacter and Pseudomonas species. FEMS Microbiology Letters 24, 133-138.

van Schie, B. J., Hellingwerf, K. J., van Dijken, J. P., ElferinK, M. G. L., VAN Diul, J. M., Kuenen, J. G. \& KoniNGS, W. N. (1985). Energy transduction by electron transfer via a pyrrolo-quinoline quinone dependent glucose dehydrogenase in Escherichia coli, Pseudomonas aeruginosa and Acinetobacter calcoaceticus (var. Iwoffi). Journal of Bacteriology 163, 493-499.

vaN Schie, B. J., DE MoOY, O. H., LinToN, J. D., VAN DiJken, J. P. \& KueneN, J. G. (1987). PQQdependent production of gluconic acid by Acinetobacter, Agrobacterium and Rhizobium species. Journal of General Microbiology 133, 867-875.

Stinnett, J. D., Guymon, L. F. \& Eagon, R. G. (1973). A novel technique for the preparation of transport-active membrane vesicles from Pseudomonas aeruginosa: observations on gluconate transport. Biochemical and Biophysical Research Communications 52, 284-290.

StouthameR, A. H. (1962). Energy production in Gluconobacter liquefaciens. Biochimica et biophysica acta 56, 19-32.

van Thienen, G. \& Postma, P. W. (1973). Coupling between energy conservation and active transport of serine in Escherichia coli. Biochimica et biophysica acta 323, 429-440.

VISSER, W., VAN Schie, B. J., DE Bont, J. A. M., VAN Dijken, J. P. \& Kuenen, J. G. (1985). Continuous culture studies on the regulation of PQQ-dependent glucose dehydrogenase in Acinetobacter calcoaceticus. Antonie van Leeuwenhoek 51, 563. 